\title{
XRD method for the determination of internal stresses in KDP crystals and their relationship to the anomalous biaxiality
}

\author{
V.M.Puzikov, V.F.Tkachenko, V.A.Tsurikov
}

Institute for Single Crystals, STC "Institute for Single Crystals", National Academy of Sciences of Ukraine, 60 Lenin Ave., 61001 Kharkiv, Ukraine

\section{Received March 18, 2014}

\begin{abstract}
Designed precision method for determining residual stresses in crystals of the KDP on the relative displacement of the rocking curves (RC), caused by the presence of tensile stress, compression from the $\{\mathbf{1 1 0}\}$ or $\{\mathbf{1 0 1}\}$, with the asymmetric geometry of the shooting at the reflection. The error in determining the relative displacement of $\mathrm{RC}$ in this case is \pm 1 arcsec. The experimentally determined bias for RD crystals KDP, grown by different methods on samples cut from the prismatic and pyramidal growth sectors of the crystal. The relation between the value of the anomalous biaxiality $2 \mathrm{~V}$ and a total displacement of RC due to the presence of internal tensile stress, compression in the crystal KDP.

Keywords: KDP crystals, shooting reflection, residual stresses.
\end{abstract}

Разработан прецизионный метод определения внутренних напряжений в кристаллах типа KDP по относительному смещению кривых дифракционного отражения (КДО), обусловленному наличием напряжений растяжения, сжатия от плоскостей $\{110\}$ или $\{101\}$, при асимметричной геометрии съемки на отражение. Погрешность определения относительного смещения КДО при этом составляет \pm 1 arcsec. Экспериментально определены смещения КдО для кристаллов KDP, выращенных различными методами на образцах, вырезанных из призматического и пирамидального секторов роста кристалла. Установлена взаимосвязь величины аномальной двуосности $2 V$ и суммарного смещенияя КДО, обусловленная наличием внутренних напряжений растяжения и сжатия в кристалле KDP.

Рентгендифрактометрический метод визначення залишкових напружень у кристалах KDP та їх зв'язок з аномальною двуосность. В.М.Пузіков, В.Ф.Ткаченко, В.А.Цуріков.

Розроблено прецизійний метод визначення внутрішніх напружень у кристалах типу KDP по відносному зсуву кривих дифракційного відбиття (КДВ), обумовленому наявністю напружень розтягування, стиснення від площин $\{110\}$ або $\{101\}$, при асиметричній геометрії зйомки на відображення. Похибка визначення відносного зсуву КДВ при цьому становить \pm 1 arcsec. Експериментально визначені зміщення КДВ для кристалів KDP, вирощених різними методами на зразках, вирізаних з призматичного та пірамідального секторів росту кристала. Встановлено взаємозв'язок величини аномальної двуосності $2 V$ та сумарного зміщення КДВ, обумовленая наявністю внутрішніх напружень розтягування, стиснення у кристалі KDP.

\section{Introduction}

Single crystals of potassium dihydrogen phosphate (KDP) and its deuterated analog
(DKDP) are widely used in modern quantum electronics, optoelectronics and nonlinear optics due to its unique properties - high laser strength, high optical homogeneity 
and structural perfection, despite the almost brought to perfection technology cultivation (a method of reducing the temperature, method of recycling the solvent) and processing crystals, laser strength of optical elements manufactured from them as significantly different from crystal to crystal, and the cross section of a crystal. Typically, nonuniformity of distribution of the threshold value for the strength of the laser crystal cross section, associated with structural defects and their distribution over the volume of the crystal grown, as well as internal stresses from [4-7]. The presence of internal stresses in the grown crystals, leads to the appearance of anomalous biaxiality, which is determined by the polarization-optical methods value anomalous biaxiality (angle $2 \mathrm{~V}$ ) and the degree of deformation of the conoscopic figures $\gamma[5,8,9]$. The authors of [6] using transmission electron microscopy in KDP crystals revealed the presence of inclusions of up to $4500 \AA$ rhombic phase of $\mathrm{KH}_{2} \mathrm{PO}_{4}$. Analysis of diffraction contrast showed that the inclusions with a size of $1200 \AA$ may be coherent or partially coherent boundary with the crystal matrix crystal KDP, which leads to internal stresses. The tetragonal cell KDP crystal undergoes the maximum strain along the [110] and [110]. Similarly oriented in the matrix include the rhombic phase lead to the macroscopic deformation: uniaxial tension along the [1-10] and uniaxial compression along [110]. Calculating the change $\Delta d / d$ ( $d$-value of the distance between planes) due to macroscopic internal tensile stresses along the [1-10] compression [110] give the value of $\Delta d / d=1.66 \cdot 10^{-7}$ and $\Delta d / d=-0.214 \cdot 10^{-7}$, respectively [6]. This is a very minor changes that lead to a change in the angle $\Theta<1$ arcsec. Evaluation order of the difference of the principal stresses [5] gives the value of $\sigma$ about $8 \mathrm{~kg} / \mathrm{cm}^{2}$. When the value of the shear modulus $G=12.7 \cdot 10^{10} \mathrm{dyn} / \mathrm{cm}^{2}$ for the crystal KDP [6] and the estimated value of the stress in the crystal $G \sim 8 \mathrm{kgf} / \mathrm{cm}^{2}$ [5], the change $\Delta d / d$ are $6.4 \cdot 10^{-5}$, which lead to change in the angle of rocking curve (RC) on the angle $\Delta \Theta_{1}=19 \mathrm{sec}$ for the reflection (660) and $\Delta \Theta_{2}=23 \mathrm{sec}$ for the reflection (606) in $\mathrm{CuK}_{\alpha 1}$ radiation. Appraise estimates change the angle $\Theta$, due to internal stress in the crystals KDP, made according to [5, 6], and evidence of their small size. Thus, use of high-precision measurement of the lattice parameter and the value of $\Delta d / d$ even Bond method [10] and the heat setting temperature measurement with an accuracy of $\pm 0.1^{\circ} \mathrm{C}$ do not reliably hold XRD measuring the absolute determination of the angle $\Theta$ (the accuracy of determination of the reference angle $\Theta$ on the goniometer is $\pm 18 \mathrm{sec}$ ). Apparently, because of the above reasons, in the literature there are no experimental data on measurements XRD methods, quantities and distribution of internal stresses in crystals of KDP.

Selection of the optimal values of the diffraction angles $\Theta$, giving the smallest error in the identification and survey design follows from differentiating Bragg on the parameters $d$ and $\Theta$,

$$
\Delta d / d=-\operatorname{ctg} \Theta \Delta \Theta .
$$

The best conditions for the implementation of (1) are implemented at the angles $\Theta>60$ deg., and this range of values of the diffraction angles is called precision area. From (1) it follows that for

$$
\Delta \Theta=-(\Delta d / d) \operatorname{tg} \Theta
$$

the best option of the measurement method (for small angles change $\Theta$ ) is the determination of the relative displacement rocking curve (RC) due to the presence of tensile stresses $\sigma^{-}$and compression $\sigma^{+}$. This shows that the change $\Delta d / d$ within the reflective layer under the influence of the internal macrostress cause displacement RC. The direction of the shift depends on the sign of $\Delta d / d$, i.e, availability bias RC smaller angles $\Theta$ due to the internal tensile stresses $\sigma^{-}$ and to larger angles $\Theta$ with internal compressive stresses $\sigma^{+}$. Effect of shifting the $\mathrm{RC}$ is greater, when more $\operatorname{tg} \Theta$.

It should be emphasized that the error in determining the $\Delta \Theta$ is determined not only by the accuracy of angular reference goniometric devices (GUR), but also experimentally obtained a full width at half maximum (FWHM) of rocking curve $\beta$, correct for thermal expansion coefficient $\alpha$, which for the KDP is $\sim 4.16 \cdot 10^{-5}$.

\section{Experimental}

Experimental measurements of the internal stresses in the KDP crystals were carried out to determine the displacement BWW developed by the authors, three-crystal X-ray diffractometer (TXD) [12] in $\mathrm{CuK}_{\alpha 1}$ 


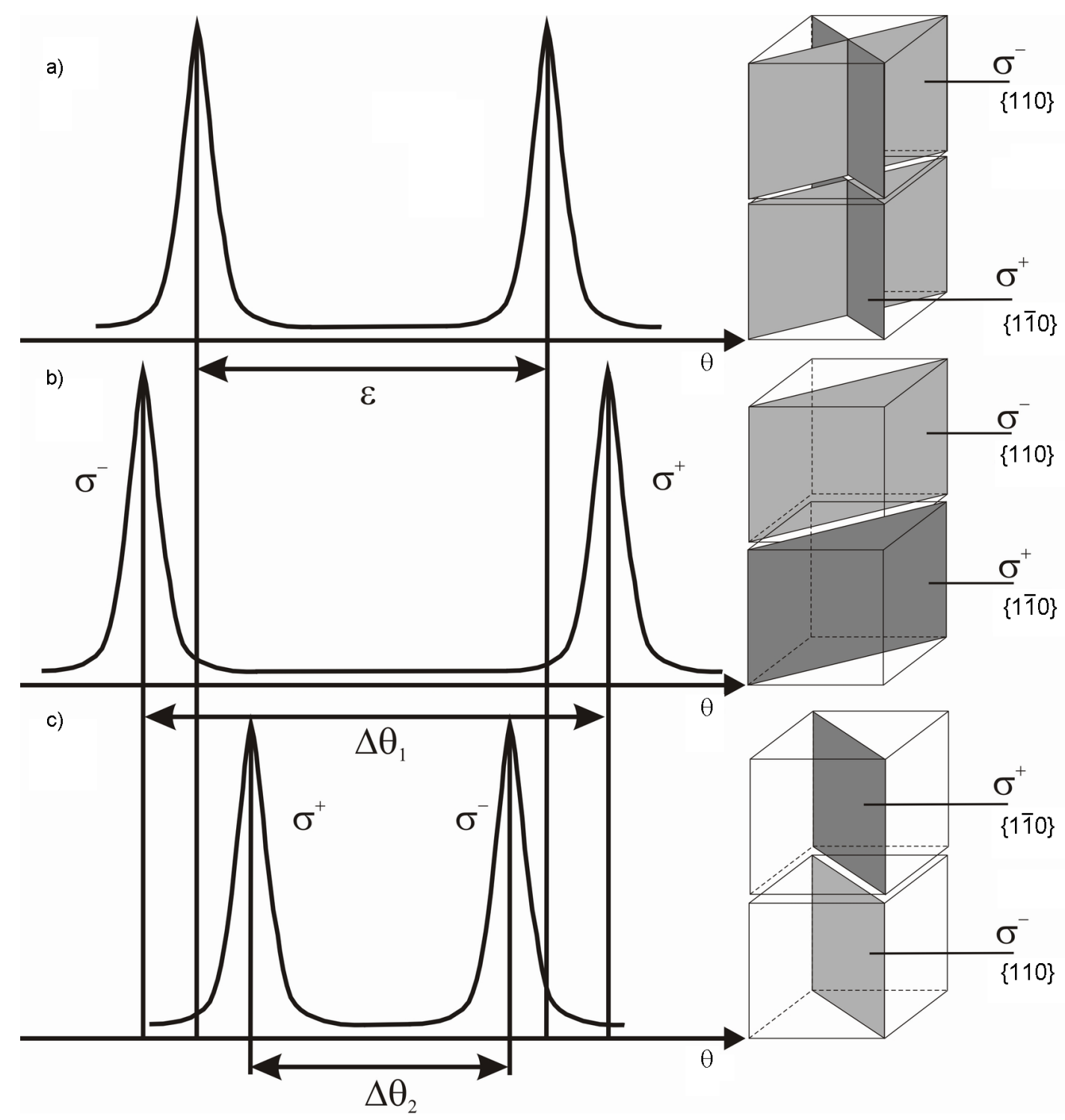

Fig. 1. Schematic position rocking curves showing the position of the test planes: (a) in the absence of stress; $(b, c)$ in the presence of internal stresses in the sample for a prismatic sector.

monochromatic radiation. The experimental FWHM $\beta$, taken at TXD, was $5-10$ sec. We used a method of disposing of the samples when there is no need to measure the absolute value of $\Theta$ and uncorrected associated with the presence of $\alpha$, since the measurements are conducted at the same temperature, the geometry and shape of the samples [13]. On the assumption of a internal tensile stress $\left(\sigma^{-}\right)$in the crystallographic direction [1-10], and compression $\left(\sigma^{+}\right)$in the [110] crystals KDP [1, 5-9], we proposed an original method for measuring internal stresses in crystal largest displacement $\Delta \Theta \mathrm{RC}$ at the appropriate orientation and arrangement of the samples in which the error in $\Delta \Theta$ is $\sim 1$ sec.
The samples were cut plumb saw, out of the prismatic and pyramidal growth of KDP crystal size $10 \times 10 \times 20 \mathrm{~mm}^{3}$ with the orientation of the (100), (010) and (001) and the deviation of the studied samples from the surface crystallographic directions $\Delta \Theta<10 \mathrm{~min}$. Then, to remove the distorted surface layer of the investigated samples were polished finish [1]. The test sample was cut in half in height. These 2 samples of size $10 \times 10 \times 10 \mathrm{~mm}^{3}$ mounted on GUR such a manner that the bottom of the sample (1) can be obtained from the asymmetrical reflection reflex (6-60), and from the top (2) reflection of (660) orientation at the surface under study sample (100) and turn the second sample relative to the first axis $\mathrm{Y}$ 
Table

\begin{tabular}{|c|c|c|c|c|c|c|c|}
\hline \multirow[t]{3}{*}{ reflex } & \multirow[t]{3}{*}{$\Theta, \operatorname{deg}$} & \multirow[t]{3}{*}{$\beta_{1}$, deg } & \multirow[t]{3}{*}{$\beta_{2}$, deg } & \multicolumn{4}{|c|}{$\left(\Delta \Theta^{\sigma_{1}^{-}}+\Delta \Theta^{\sigma_{2}^{+}}\right)$, sec } \\
\hline & & & & \multicolumn{2}{|c|}{ Method of recycling } & \multicolumn{2}{|c|}{$\begin{array}{l}\text { Method of reducing } \\
\text { temperature }\end{array}$} \\
\hline & & & & pyramid & prism & pyramid & prism \\
\hline 660 & 61.3 & 16.3 & 106.3 & 18 & 30 & 30 & 70 \\
\hline 606 & 65.2 & 18.3 & 112.1 & 34 & 2 & 62 & 4 \\
\hline
\end{tabular}

through an angle $180^{\circ}$ with the steer angle $\varepsilon$ about the axis $\mathrm{Z}$ by several tens arc-seconds. The primary X-ray beam at the same time hitting the 1 and 2 sample. When shooting moving geometry, when the primary beam with the surfaces of the crystal was small angle $\beta_{1}$ for reflections (660) were recorded $\mathrm{RC}$ from these samples. RC position is as follows (Fig. 1).

As can be seen from Fig. 1, at the fall of the X-ray beam geometry and the presence of rotation $\varepsilon$ between the first and second samples (Fig. 1a.) For voltages $\sigma_{1}^{-}$in the first crystal RC is shifted to lower angles and for the stresses $\sigma_{2}^{+}$in the second sample RC shift toward larger angles (Fig. 1b). The total offset voltages caused by RC $\sigma^{-}$ and $\sigma^{+}$from the two samples was

$$
\Delta \Theta_{1}=\varepsilon+\Delta \Theta^{\sigma_{1}^{-}}+\Delta \Theta^{\sigma_{2}^{+}} .
$$

To obtain the dependence of $\Delta \Theta_{h k l}\left(\operatorname{tg} \Theta_{h k l}\right)$ the value $\varepsilon$ determined by the reflections of (100) [13]. The nature of this relationship can be calculated due to the presence of internal stresses $2 \sigma^{-}, \sigma^{+}$and the first and second sample [13]

$$
\Delta d / d=-\operatorname{tg}\left(\Delta \Theta_{h k l}-\varepsilon\right) \operatorname{ctg} \Theta_{h k l} .
$$

When recording $\mathrm{RC}$ in geometry of incidence and reflection of the asymmetric type of plane ( $h k 0)$ and $(h-k 0)$ (shown in Fig. 1c) total displacement of $\mathrm{RC}$

$$
\Delta \Theta_{2}=\varepsilon-\Delta \Theta^{\sigma_{1}^{-}}-\Delta \Theta^{\sigma_{2}^{+}} .
$$

The difference values

$$
\Delta \Theta_{1}-\Delta \Theta_{2}=2\left(\Delta \Theta^{\sigma_{1}^{-}}+\Delta \Theta^{\sigma_{2}^{+}}\right)
$$

can not determine with some accuracy the value of $\varepsilon$, and the right to receive the total displacement of RC due to the presence of $\sigma^{-}$ and $\sigma^{+}$in the samples. The error in determining the total angular displacement of the RC in this case is, with simultaneous registration of $\mathrm{RC}$ for the two samples on the TXD. When the crystal orientation of the surfaces of the samples (100) (010) (001) is easy to implement displacement measuring $\mathrm{RC}$ due to the presence and $\sigma^{-} \sigma^{+}$ to [101] or [011] (prismatic crystal growth portion) to the sample plane $\mathrm{ZX}$ or $\mathrm{ZY}$, rotated by $180 \mathrm{deg}$. around the second sample axis $\mathrm{X}$ or $\mathrm{Y}$. Record RC measurement and calculation are carried out similar to that described above for the asymmetric registration RC for reflections (606) and (066). The proposed layout, and geometry of the samples can be taken, in principle, to implement any crystallographic orientation, preparing test samples with a corresponding crystallographic orientation of the sample. For quantification, the separate determination of the sign changes $\Delta d / d$ and due to tensile stress $\sigma^{-}$and compression $\sigma^{+}$of the proposed method, measurements should be made by Bond [10]. The error of this increase several times, as determined by the absolute value of the angle of reflection, on goniometer, which has an error ( \pm 0.005 deg.).

\section{Results and discussion}

On the TXD [12] in the $\mathrm{CuK}_{\alpha 1}$ radiation studied sized single crystals KDP $260 \times 130 \times 520 \mathrm{~mm}^{3}$ grown by recycling solvent rectangular orientation primer (001) at a rate of $1 \mathrm{~mm} /$ day in the optical axis direction (Z), after storage at room temperature, the crystal within 30 years who had a slight internal stress in order to determine the error of the method and single crystals grown on the seed point section of $5 \times 5 \times 5 \mathrm{~mm}^{3}$ oriented edges (100) (010) (001) with a growth rate of about $10 \mathrm{~mm} /$ day in the optical axis, $70 \times 70 \times 80 \mathrm{~mm}^{3}$, by lowering the temperature. From the grown crystals pyramidal and prismatic sector growth, the samples were cut $10 \times 10 \times 20 \mathrm{~mm}^{3}$ oriented edges (100) (010) (001). To determine the displacement RC due to the presence in 


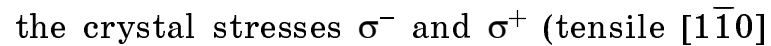
and compress [110]), the lower sample was placed on the device having two mutually perpendicular linear displacement and two angular inclination of the sample, (001) plane, and mounted on the top with a lower rotatable around the axis $y$. This setup allowed the sample to implement the measurement procedure described in the previous section, with simultaneous recording of $\mathrm{RC}$ of asymmetric reflexes $(660)$ and $(6 \overline{6} 0)$. To determine the total offset RC due to internal tensile stress, compression directions [101],

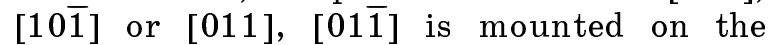
lower plane of the sample (100) or (010) and the upper turns around the $x$ or $y$ axis 180, which allows simultaneous recording $\mathrm{RC}$ for asymmetric reflexes $(606),(60 \overline{6})$ or $(066)(06 \overline{6})$ from the two samples to measure the displacement caused by the RC to internal stresses in the samples. Table shows calculated values of the angle of Bragg reflections (660), (606) crystals KDP, for $\mathrm{CuK}_{\alpha 1}$ radiation. The values of angle $\beta_{1}$ with asymmetric shooting at small angle of incidence to the plane of X-ray beam (100), (010) or (001), and the value of the angle $\beta_{2}$ with a large angle of incidence to these planes, when implemented asymmetric RC recording scheme shown in Fig. 1b, c.

Table shows the experimental values of the total displacement $\mathrm{RC}\left(\Delta \Theta^{\sigma_{1}^{-}}+\Delta \Theta^{\sigma_{2}^{+}}\right)$due to the presence of internal tensile and compression stresses in the crystal.

For reflection (606), for which the Bragg angle of reflection is $\Theta=65^{\circ} 10^{\prime} 20^{\prime \prime}$, the error in determining the angular displacement of the $\mathrm{RC}$ due to the presence of $\sigma^{-}$and $\sigma^{+}$to \pm 1 sec gives an error in the definition of $\Delta d / d= \pm 2 \cdot 10^{-7}$. The presence of bias in the samples RC at $2^{\prime \prime}-62^{\prime \prime}$ (Table) leads to changes in $\Delta d / d=\left(4.72 \cdot 10^{-7}-11.43 \cdot 10^{-5}\right) \pm 2 \cdot 10^{-7}$ or $\sigma=59.94 \cdot 10^{3}-145.16 \cdot 10^{5}$ dynes $/ \mathrm{cm}^{2}$, respectively. Thus, the proposed method of determining the relative displacement of the RC, due to the presence of stresses in the crystal with an accuracy of \pm 1 sec, gives the error in $\sigma= \pm 25.4 \mathrm{Dyn} / \mathrm{cm}^{2}$ or $25.91 \cdot 10^{-3} \mathrm{kgf} / \mathrm{cm}^{2}$ (at the value of the shear modulus $G=$ 12.7.10 10 Dyn $\left./ \mathrm{cm}^{2}[6]\right)$. The evaluation of the internal stress in the crystals significantly greater than the values given in [6], and is consistent with the estimates of internal stresses given in [5]. One of the causes of internal stress in the crystals KDP, may be coherent and semi-coherent boundary interface between the packet layer

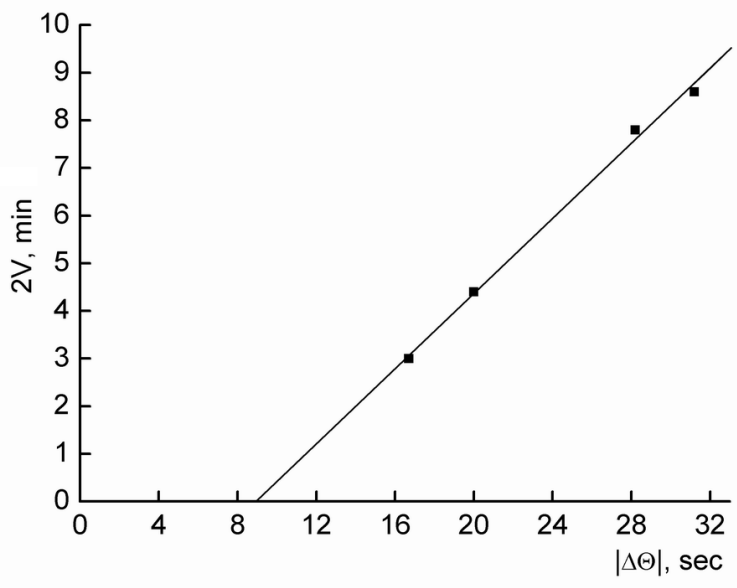

Fig. 2. The dependence of the anomalous biaxiality $2 \mathrm{~V}$ of the total displacement RC due to the presence of internal stresses.

growth [14]. From the analysis of the experimental data presented in the table it can be concluded that samples cut from the prismatic sector growth dominated $\sigma$ tensile stress and compression $\sigma^{+}$in the [110] and $[1 \overline{1} 0]$. The component of the value of the internal stress in the [101] and [101] has a value of about $6-7 \%$, that is in the growth sectors of the prismatic crystals KDP, grown by different methods are predomi-

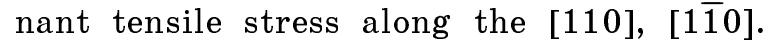
Results of the polarization-optical investigations abnormal biaxiality $(2 \mathrm{~V})$ and the position optical axis of the plane $(\mathrm{OAP}-\gamma)$ in the crystals KDP $[1-5,8,9,16]$ indicate that samples cut from the growth sectors of the $\{100\}$ there is one predominant direction of $\gamma$. This confirms the results of our measurements of the crystallographic direction of the prevailing distribution of internal stresses. The situation is different $\operatorname{OAP}(\gamma)$ is observed for samples cut from the pyramidal growth sectors of the crystal $\{101\}$ when $\gamma$ has several directions [6]. As seen from the table of data sector growth of $\{101\}$ are observed internal tensile stress in the [110] direction and [101]. Despite the fact that the growth sectors Krystal $\{101\}$ prevail $\sigma$ stresses and $\sigma^{+}$in the [101] or [011], and the value component [110] is sufficiently large and only 2-fold lower than in the [101] or [011] (Table).

A number of studies $[1-6,8,9,14-16]$ manifestation of anomalous biaxiality in the crystals of the KDP group associated with the presence of these structural defects leading to the appearance of internal stresses, which is a measure of the value of $2 \mathrm{~V}$. To test this 
hypothesis, KDP crystals were grown by lowering the temperature at the point seed. It is known that the growing face of the prism (100) crystals KDP, grown on a point seed, captures impurities much more than face of the pyramid (101) and, therefore, has a lower structural quality [17].

The samples were cut from the prismatic sector growth. Measurement of the total displacement RC due to the presence of internal tensile stresses $\sigma$ and $\sigma^{+}$compression along the [110], [1-10] for reflections (660), (6-60) was measured by TXD. For a comparative analysis of the values $2 \mathrm{~V}$ (averaging 5 points) measured the polarization-optical method, were taken from [5, 8, 9]. As a result, we obtained a linear relationship

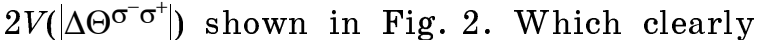
shows the relationship of anomalous biaxiality $2 \mathrm{~V}$ in KDP crystals with the magnitude of the internal stresses.

\section{Conclusions}

Designed precision method for determining internal stresses in crystals of the KDP. The method is based on measurements of the relative displacement of the $\mathrm{RC}$ under asymmetric shooting of reflections (660), (606), taken by TXD for the orientation of the faces of the sample (100) (010) (001). The error in determining the total relative displacement $\mathrm{RC}$ due to internal tensile stresses, compression crystal is $\pm 1 \mathrm{sec}$, which gives the error in the determination of $\sigma=0.26 \mathrm{gs} / \mathrm{mm}^{2}$. In the samples cut from the prismatic sector growth dominated only tensile and compressive stresses in the [110], [1-10] while for samples cut from the pyramidal growth sector and the voltage present in the [101] and [110]. A linear dependence of the internal stress in the crystal, resulting in the displacement of the
RC for asymmetric reflexes shot at the TXD with the magnitude of the anomalous biaxiality $2 V\left(\left|\Delta \Theta^{\sigma-\sigma+}\right|\right)$.

\section{References}

1. V.M.Puzikov, V.I.Salo, M.I.Kolybaeva at al., KDP/DKDP Single Crystals for High-Power Lasers: Growing, Properties, Application, Institute for Single Crystals Publ., Kharkov (2004) [in Russian].

2. L.V.Atroschenko, M.P.Borodich, V.I.Salo et al., USSR Inorg. Mater. Bull., 30, 661 (1994).

3. V.I.Bredihin, S.P.Kuznetsov, Crystall. Rep., 32, 252 (1987).

4. V.M.Puzikov, I.M.Pritula, M.I.Kolybaeva, Influence Effects on Structure-sensitive Properties of Single Crystals KDP, Institute for Single Crystals Publ., Kharkov (2009) [in Russian].

5. A.V.Belyustin, N.S.Stepanova, S.S.Fridman, USSR Inorgan. Mater. Bull., 8, 1624 (1972).

6. E.I..Suvorova, A.A.Chernov, Crystall.y Rep., 39, 907 (1994).

7. Yu.M.Fishman, Crystall. Rep., 17, 607 (1972).

8. V.A.Shamburov, I.V.Kucherova, Crystall.Rep., 10, 658 (1965).

9. A.V.Belyustin, V.N.Portnov, N.S.Stepanova, Crystall. Rep., 4, 719 (1969).

10. W.L.Bond, Acta Crystall., 13, 281 (1960).

11. L.I.Gladkih, S.V.Malihin, A.T.Pugachev, Diffraction Methods for Analyzing Stress. Theory and Experiment, NTU "KhPI", Kharkov (2006) [in Russian].

12. V.F.Tkachenko, M.A.Rom, A.A.Babichenko et al., Instrum. Exper. Techn., 2, 277 (1992).

13. USSR Autor's Cert. 1702265 (1991).

14. V.M.Puzikov, V.F.Tkachenko, V.A.Tsurikov, Functional Materials, 18, 71 (2011).

15. V.M.Puzikov, V.F.Tkachenko, V.A.Tsurikov, Functional Materials, 15, 556 (2008).

16. L.V.Atroschenko, T.N.Bogdanova, V.G.Vasilchuk et al., Inorgan. Mater., 28, 867 (1992).

17. I.M.Pritula, M.I.Kolybayeva, V.I.Salo et al., Opt. Mater., 30, 98 (2007). 